\title{
13. Yüzyılda Moğolların Diplomasi Anlayışı Üzerine Bazı Notlar*
}

\author{
Oktay BERBER $^{* *}$
}

\author{
13. Yüzyılda Moğolların Diplomasi Anlayışı Üzerine Bazı \\ Notlar
}

Özet

Devletlerarası ilişkileri ifade eden diplomasi kavramının Büyük Moğol İmparatorluğu dönemindeki anlamı oldukça önemlidir. Elçiler üzerinden yürütülen bu ilişkiye dair Çingiz Han zamanından itibaren başta seyahatnameler olmak üzere çeşitli dönem kaynağında bilgiler bulmak mümkündür. Bu kaynaklardaki bilgilerden hareketle Moğollardaki diplomasi anlayışına dair bir takım hususlar tespit edilebilir. Bu çalışmada 13 . yüzyılda Moğolların diplomasi anlayışı içerisinde elçilerin uluslararası ilişkilerdeki rolü ve önemi, Moğol idareciler tarafından karşıllanma biçimleri, imparatorluk içerisinde oluşturulan posta sistemi ile diplomasi arasındaki ilişki, diplomatik evlilikler, Moğolların muhataplarına gönderdikleri mektuplarda kullandıkları ifadelerin diplomasi açısından değeri gibi konulara değinilmiştir. Sonuçta 13. ve 14 . yüzyıldaki başarılı Moğol ilerleyişinin sebeplerinden biri olarak teşkilatlı bir devlet idaresinin varlı̆̆ hususuna işaret edilmiştir.

Anahtar Kelimeler: Büyük Moğol İmparatorluğu, ilhanlılar, Moğol elçileri, Posta (Yam) sistemi

\author{
Some Notes on Understanding of Diplomacy of \\ Mongols in $13^{\text {th }}$ Century
}

Abstract

The meaning attached to concept of diplomacy, which denotes the relations between states, was very important during the Great Mongol Empire. Information as to this relation carried out by messengers can be found in various sources of various periods such as travel books, especially from the time of Genghis Khan on. Issues such as the role and importance of messengers in diplomatic approach of the Mongols in the $13^{\text {th }}$ century, their way of being welcome by the Mongol rulers, the relation between the postal system established in the empire and diplomacy, diplomatic marriages and the diplomatic value of the expressions used through the Mongols in the letters they sent to their addresses are discussed in this study.

Key Words: Great Mongol Empire, Ilkhanids, Mongol Ambassadors, Postal (Yam) System

\section{Giriş}

1206 yılında düzenlenen büyük kurultayda Temuçin'in Çingiz unvanını almasıyla Moğol İmparatorluğu kurulmuştu. Çingiz Han 1227 yılındaki vefatına kadar birbirini izleyen askerî seferler neticesinde öldüğünde oğullarına Mançurya'dan Doğu Avrupa'ya kadar uzanan çok büyük bir devlet

\footnotetext{
* Çalışmada ele alınan konunun son derece geniş olması ve makale boyutunu aşması nedeniyle başlıkta "...Bazı Notlar" ibaresinin kullanımı tercih edilmiştir. Ayrıca konunun çok daha farklı kaynaklarla ve etrafı bir şekilde ele alınması Moğol tarihi çalışmalarına önemli bir katkı sağlayacaktır.

** Oktay BERBER, Dr.Öğr.Üyesi., Eskişehir Osmangazi Üniversitesi, Tarih Bölümü, oberber@ogu.edu.tr, ORCID ID orcid.org / 0000-0002-1609-3171
} 
Oktay BERBER

miras olarak kalmıştı. Çingiz Han hayattayken ele geçirilen toprakların hâkimiyeti de oğulları arasında paylaşılmıştı. ${ }^{1} 1229$ yılında toplanan büyük kurultayın ardından devam eden faaliyetlerle sınırlar daha da genişlemiş ve neticede 13. ve 14. yüzyıllar Asya ve Dünya tarihi açısından önemli bir dönem olarak tarihteki yerini almıştır.

Her ne kadar diplomasi kelimesi 18. yüzyılla birlikte kullanılmaya başlansa da devletler arası ilişkileri ifade etmesi bakımından tarihte pek çok siyasi yapı için önemli bir unsur olmuştur (Ergüven, 2016, s. 112-113; İskit, 2007, s. 3). Meseleye devletler arası ilişki açısından bakıldığında Moğolların sınırlarının genişlediği ve büyük devletin ortaya çıktığı dönem için istihbarat bilgisinin önemi ve nasıl elde edildiği konusu gündeme gelmektedir. Bu bağlamda Moğolların askerî taktik istihbaratı ve stratejik istihbarat olmak üzere iki tür bilgi sağladıklarını belirtmek gerekir. Stratejik istihbarat daha çok diplomasiye ve ön askerî seferlere dayanmaktaydı. Ön seferler sırasında Moğollar bilmedikleri topraklar hakkında mümkün olduğunca bilgi toplamaya çalışıyorlardı. Bu doğrultuda batı topraklarına yapılan ilk keşif seferi olarak 1219 yılında başlayan ve 1224'e kadar süren sefer gösterilebilir ki, böylece Doğu ve Orta Avrupa hakkında ilk bilgiler toplanabilmiştir (Ver, 2011, s. 111).

Morris Rossabi'ye göre Çingizoğulları dönemi tam anlamıyla küresel tarihe doğru önemli bir adım olarak nitelendirilmektedir. Çünkü Avrupalıların ilk kez Asya'ya ulaşmasıyla buradaki kültürel ve ekonomik gelişmeler diğer kıtaya yansımıştır. Pax Mongolica (Moğol Barışı) adı verilen dönem zanaatkârların, tacirlerin ve misyonerlerin İtalya ve Fransa'dan Çin'e seyahat etmelerini mümkün kılmıştır (Rossabi, 2008, s. 5). Gerek temsilcilerin Avrupa'dan Asya'ya seyahatlerinin sayısındaki artış ve gerekse Moğol İmparatorluğu'nun elde ettiği konum bakımından Güyük Han'ın tahta çıkış merasimi ile ilgili kayıtlar oldukça önemlidir. Bu dönemde pek çok kişinin Moğol idaresi tarafından elçi sıfatıyla kabul edildiği görülmektedir. Polonus’un kayıtlarına göre, Güyük Han'ın tahta çıkma merasimine farklı ülkelerden 3.000 elçi katılmıştır (Ver, 2011, s. 111). Ancak Carpini bu sayının Moğol devlet kâtiplerinin söylediğine göre 4.000'den fazla olduğunu bildirmektedir. Bu elçilerin bir kısmı vergi, bir kısmı hediye getirmiş, kimi şahsen gelip hakana bağlıı̆̆ını bildirmek istemişti. Elçi olarak gelenlerin bir kısmı ise Moğollar tarafından çağrılmış, bir kısmı da kendi ülkelerini idare eden hükümdarların valileri olarak gelmişlerdi (2000, s. 120).

Çingiz Han ile başlayan ve sonrasında devam eden dönem ile ilgili tarih yazımında imparatorluğun faaliyetleri konusunda en fazla değinilen konuların başında askerî seferler ve bu seferlerin etkileri gelmektedir. Çağdaşı devletler üzerinde oluşturduğu etki bakımından Moğol İmparatorluğu'nun askerî seferlerinin ön planda tutulması ve tarih yazımında bu hususun ağırlık kazanması

\footnotetext{
${ }^{1}$ Buna göre Ögedey büyük han olarak belirlenmişti. Büyük oğlu Cuci'ye Altay Dağları ile Batı Sibirya'dan başlayarak İdil-Ural bölgesi ve ötesi bırakılmıştı. Cuci babası hayatta iken öldüğünden bu topraklardaki hâkimiyet hakkı oğlu Batu'ya geçmişti. íkinci oğlu Çağatay ise Beşbalık'tan Ceyhun'a kadar olan toprakları idare edecekti. Küçük oğlu Tuli ise Odtiğin sıfatıyla asıl Moğol topraklarında hâkimiyet sürecekti (Ötemiş Hacı, 2009, s. 30-31; Cüveynî, 1999, s. 96; Koç, 2018, s. 153-154).
} 
oldukça doğal karşılanacak bir durumdur. Ancak devletin elde ettiği başarıların yalnızca büyük bir baskıyla veya yıkıcı, yok edici bir unsur olarak gösterilen askerî faaliyetlerle açıklanması bir sorun olarak karşımıza çıkmaktadır. Çingiz Han ile kurulan Moğol İmparatorluğu'nun 13. ve 14. yüzyıllarda elde ettiği başarılarda askerî faaliyetlerin iyi neticeleri kadar yönetim organizasyonu, iktisadî, siyasi, içtimai unsurlar gibi çeşitli hususlar da etkili olmuştur. Bu bağlamda Moğol İmparatorluğu'ndaki diplomasi anlayışının, unsurlarının, Moğol idarecilerin diğer devletlerle ilişkilerinin ele alınması konuya farklı bir bakış kazandıracaktır.

\section{Diplomatik ilişkilerde Elçiler ve Elçi Kabulleri}

Diplomaside elçilerin rolü Moğol çağında da son derece önemlidir. Aslı Türkçe olan elçi kelimesi Farsça, Arapça gibi Avrasya dillerine de geçmiştir. Hatta bu geçişte 13. ve 14. yüzyıllardaki Moğolların faaliyetlerinin etkili olduğu ileri sürülmektedir. Araştırmacılar elçi kelimesini uzun süre "büyükelçi, yabancı devletlerdeki hükümet temsilcisi" gibi bir anlamda kullanmışlardır. Marcel Erdal ise kelimenin 13. yüzyıl öncesinde "devlet adamı" anlamında kullanıldığını ve önceleri Moğollarda "elçi, kurye" anlamında yer aldığını ifade etmektedir. Igor de Rachewiltz ise Moğolların Gizli Tarihi'nde elçi kelimesinin Otrar olayında devlet işlerinde çalışan tüccar olarak kullanıldığını belirtmektedir. Fakat bu yorum henüz uzmanlar tarafından yeterince kabul görmemiştir (Ver 2016). Ancak bu noktada diplomatik görevlerin her seferinde tamamen bu işlerle uğraşan ve elçi olarak hizmet veren kişiler tarafından yapılmadığını belirtmek gerekir. Özellikle ticaretle uğraşan ve bu vasfıyla çeşitli ülkelere seyahat eden kişiler arasında hükümdarın güvendiği bir tüccara da diplomatik görevler verilmektedir. Tacir-elçi olarak isimlendirilebilecek bu kişiler temsil ettikleri hükümdarın siyasi meselelerinin karşı tarafa aktarılmasında yetkilendirilmiş olup, bu görevle birlikte iktisadî faaliyette de bulunmaktaydılar (Kalan, 2016, s. 185-190). Bu sebeple Otrar olayında bahsi geçen tüccarın elçi olarak değerlendirilmesi normal karşılanabilecek bir durumdur.

Elçilerle ilgili kullanılan kavramlar konusunda Altın Orda Devleti'ne ait yarlık ve bitiklerde geçen yolavçı kavramından söz edilebilir. Örneğin 24 Nisan 1398 tarihli Timur Kutluğ Han'ın yarlığında bu terim geçmektedir ve "klavuz, elçi" anlamında değerlendirilmektedir (Özyetgin-Kemaloğlu, 2017, s. $50,52,146)$.

Moğolların batı ile ilişkilerinde diplomasi ve bu çerçevede elçiler son derece önemlidir. Özellikle Ögedey ile birlikte batıya doğru yoğunlaşan Moğol seferleri, Moğollara yönelik korku ile karışık bir merak duygusu uyandırmış, Moğol topraklarına Papalık tarafından elçiler gönderilmeye başlanmıştır. Bu kapsamda Moğollara gönderilen elçiler Dominiken misyonerler olup bunlardan ilkinin Andre de Longjumeau, ikincisinin de Ascelin de Cremone olduğu ifade edilmektedir (Türker ve Karaduman, 2018, s. 724-725).

1235 yılında bir devlet görevlisi olarak Deşt-i Kıpçak’a gönderilen Macar rahip Julian'ın aktardığı bilgilere göre Batu Han tarafından Macaristan'a on üç elçi gönderilmiştir. Hatta Batu'nun bu diplomatik çabasına rağmen kendisine bir karşılık verilmediği de ifade olunmaktadır (Özcan, 2010, s. 93, 98). Julian'ın buradaki kayıtlarında Moğolların diplomasiye öncelik verdiğini ve bu sebeple birkaç kez girişimde bulunduğunu söylemek mümkündür. Bu noktada yıkıcı olarak nitelenen Moğol 
Oktay BERBER

askerî seferlerinin ortaya çıkışında Moğol idarecileri dikkate almayan ve diplomatik çabaları adeta görmezden gelen tarafın etkisinin olduğunu söylemek yanlış olmasa gerektir.

Kendilerini temsil etmek üzere gönderilen kişilerin yalnızca Moğol olmadığını ifade etmeliyiz. Fransız gezgin Yvo deNarbonne'ye ait bir mektupta Moğolların elçilerinden bahis olunarak Dalmaçya Valisi'nin biri İngiliz kökenli olmak üzere sekiz Moğol elçiyi esir aldığı ifade edilmektedir. Ayrıca Friar Julian 1235-1236'daki ilk yolculuğunda görüştüğü bir Moğol elçisinin Rusça, Kumanca, Almanca, Farsça ve Moğolca konuştuğunu kaydetmektedir. Bu gibi bilgiler Moğol elçilerinin pek çok dil bilen, donanımlı insanlar olduklarını göstermektedir (Ver, 2011, s. 110).

Moğol hanına gönderilen kişilerin görevlerini tamamlamaları akabinde bu kez ters istikamette elçi olarak görevlendirildiklerine dair örnekler de söz konusudur. Ortadoğu'da dengelerin değişmesiyle birlikte Illhanlı yöneticileri batıya elçiler göndererek ittifak arayışına girmişler ve elçilerle birlikte gönderilen mektuplarda dostane ilişkiler kurulmaya çalışılmıştır (Roux, 2001, s. 371-372; TürkerÜkten, 2014, s. 339). Abaka Han'ın Memlûklere karşı batı ile ittifak arayışı kapsamında 1272 yılında $X$. Gregorius'un Papalık görevine yeni başlamasından sonra girişimde bulunulmuştur. Daha önce 1260 yılında batıdan Hülagu Han'a gönderilen ve ardından İran'da kalan David adlı elçi Abaka Han tarafından 1273 yılında görevlendirilmiştir. Elçi David 1274 yılında ekümenik konsilin toplandığı Lyon'a ulaşmıştır. Ancak Abaka'nın istediği olumlu bir netice alınamamıştır. Bundan sonra 1276 yılında Vatikan'a Papa XXI. loannes'e gönderilen James ve John Vassalli isimli iki Gürcü Hıristiyan elçi ile 1277 yılında Londra'ya gönderilen elçinin girişimlerinden de bir sonuç alınamamıştır (Rossabi, 2008, s. 90-91). Memlûkleri yenerek onları Suriye ve kutsal topraklardan atmak amacıyla 1286 ylında bu kez Argun Han yeni bir ittifak arayışına girmiştir. Argun Han'ı yeniden bu girişime yönelmesinde Papalık'ta ve Avrupa'da değişen dengelerin önemi söz konusudur. Argun Han, elçilik heyetinin iyi donanımlı, pek çok yer görmüş, birkaç yabancı dili konuşabilen bir yapıda olmasına önem vermekteydi. Çünkü bu şekilde elçilik heyetinin ikna kabiliyetinin yükseleceğine ve istediği ittifakı sağlayabileceğine inanmaktaydı. Bu doğrultuda Hanbalık'tan hareketle Tebriz'e kadar gelmiş, pek çok yer görmüş, Çinliler, Türk boyları, Ermeniler ve Farslarla görüşmeler yapmış olan Rabdan Savma adlı kişiyi elçi olarak görevlendirmiştir. Ayrıca Rabdan Savma'nın Ortadoğu Nasturi Kilisesi'nde konumunun olması ve Patrik Yaballaha'ya yakınlığının bilinmesi de bu görevlendirmede önemli hususlardandır. Rabdan Savma kabul ettiği bu görev ile illhanlı sarayından Avrupa liderleri ile görüşmeye giden ve seyahatlerini kayda geçiren, aynı zamanda Çin'den Batı Avrupa'ya giderek gördüklerini yazan ilk elçi unvanlarını kazanmıştır. Savma, seyahatnamesinde batılı hükümdarlara yazılan mektupların içeriğinden söz etmediğinden, İlhanlı yöneticilerinin ne tür vaatlerde bulunduklarını bilememekteyiz. (Rossabi, 2008, s. 99-101). Ağustos 1287'de Fransa'ya ulaşan Rabdan Savma, Fransa Kralı IV. Philippe'in görevlendirdiği kişilerce karşılanmış ve Paris'e kadar kendisine eşlik edilmiştir. Büyük bir merasimle Paris'te karşılanan Savma, üç gün dinlendirildikten sonra Kral Philippe'in huzuruna çıkmıştır. Fransa kralının Savma'yı ayakta karşılaması ve ona eşiti gibi davran- 
ması görüşmenin seyri açısından oldukça önemlidir. Görüşmenin başında Kudüs ile ilgili Memlûklere karşı İlhanlı hükümdarı Argun'un teklifini ve mektubunu ileten Moğol elçisine karşı Fransa kralının verdiği cevapta Kudüs'ün yeniden ele geçirilmesi ile ilgili ilhanlıların kararlı görüntüsünden etkilendiği görülmektedir (Rossabi, 2008, s. 144 vd). Fransa Kıralı IV. Philippe'in Argun Han'ın teklifine çok sıcak yaklaşmasına karşın, gerçekte böyle bir Haçlı seferinin yapılmasına imkân olmadığını belirtmek gerekir. Çünkü dönemin Avrupası'nda devletlerarası ilişkilerde ciddi sorunlar söz konusuydu. Ayrıca Fransa içinde de bir takım idari problemler vardı. Kral Philippe'in bu Haçlı seferini bahane ederek şövalye tarikatlarının mülkiyeti altındaki toprakları devlete geçirmek gibi bir amacı olduğu da ileri sürülmekle birlikte konumuz dışında kalacağı için burada değerlendirilmemiştir. Bu nedenlerle Kral Philippe'in bir Haçlı seferinden önce çözmesi gereken daha öncelikli sorunlar mevcuttu.

Diplomatik ilişkiler devletler arasında ticari rekabet ve kâr elde etme ile ilgili ortak çıkarlara etki eden bir unsur olarak karşımıza çıkmaktadır. Bu çerçevede Yuan Hanedanlığı ile Hindistan bölgesindeki yerel idareler arasındaki ilişkileri göstermek mümkündür. Çünkü 13. ve 14. yüzyıllarda Yuan Hanedanlığı yöneticileri Güney Asya'ya ayrı bir önem vermişlerdir. Yalnızca 1272 ile 1296 yılları arasında on altı diplomatik temsilci Hindistan'a gönderilmiştir. Bu elçilerin bir kısmı Hindistan’ın güneybatısındaki Malabar kıyısına veya Coromander kıyısındaki Mabar Krallığı'na gönderilmiştir. Aynı dönemde önemli bir kısmı Hindistan'daki Kollam ve Mabar'dan olmak üzere Yuan Hanedanlığı'na on yedi elçi gönderilmiştir (Sen, 2006, s. 301-302). Elçilerin bölgeye gönderilmesiyle Kubilay Han Güney Asya'da diplomatik misyonlar oluşturmaya çalışmıştır. Bu türden faaliyetler bir yandan Kubilay Han'ın Moğol İmparatorluğu'nun büyük hanı olarak tanınmasına da katkı sağlarken diğer yandan Çin ve Güney Hindistan arasındaki ticari ve diplomatik ilişkileri kuvvetlendirmiştir. Sonuç itibarıyla Ming Hanedanlığı dönemine gelindiğinde ünlü Zheng $\mathrm{He}^{\prime} \mathrm{nin}^{3}$ Güney Asya ve ötesine büyük denizcilik gezilerinin temellerinin atılması 13. yüzyılın ikinci yarısında Kubilay Han döneminde gerçekleşmiştir (Sen, 2006, s. 326).

Moğolların elçileri kabulleri ile ilgili olarak bir takım hususlar tespit edilebilmektedir. Öncelikle elçi kabulünün yalnızca Moğolların hükümdarı tarafından yapılmadığını belirtmek gerekir. Bu hususta Spuler, hükümdarla birlikte prens ve vezirlerin elçileri kabul edebildiklerini ifade etmektedir. Ancak eğer herhangi bir elçi Moğol hükümdarı için gönderilmişse, mutlaka huzura kabul edilmek üzere başkente yönlendirilmekteydi. Buna karşın elçi kabulünde valilerin bir hakkının bulunmadığı ifade edilmektedir (1987, s. 394).

\footnotetext{
${ }^{2}$ Argun Han'ın Kral IV. Philippe'e gönderdiği ifade olunan mektubun görüntüsü Ek-1'de yer almaktadır.

${ }^{3}$ Asıl adı Ma He olan Zheng He, 1371 yılında Çin'in güneyinde Yünnan'da bir Müslüman ailede doğmuştur. 1381 yılında Ming Hanedanlığı Yünnan'ı ele geçirince Ma He de 11 yıl sürecek esir hayatı yaşamıştır. Savaş esiri olarak hadım edilmiş ve hizmetçilik göreviyle Yan Prensi Zhu Di'nin yanına verilmiştir. Zhu Di'nin başlayan ayaklanmasında önemli başarılar elde eden Ma He'ye Zhu Di tarafından Zheng He adı verilmiş ve bundan sonra amiralliğe kadar yükselmiştir. Zheng He'nin büyük bir denizci olarak faaliyetleri de bundan sonra gerçekleşmektedir (Wei, 2014, s. 26-30; Guangqi, 1993, s. 329-343; Eberhard, 1987, s. 278).
} 
Oktay BERBER

Çin elçisi Shao Hung'un kayıtlarına göre Moğollar elçi olarak görevlendirilen kişiye emir ulağı anlamında xiuan cha demektedirler. Hükümdarın sarayı veya üst düzey devlet adamı tarafından gönderilen elçilere gittikleri her yerde askerî karakollarda hürmet edilmekte, elçilerin makam ve derecesine bakılmaksızın eşit ve adil davranılmaktadır. Elçiler kabul salonunda konaklamakta, onlara davul ve flüt çalınmaktadır. Şehir kapısında ise elçiler için şarkı ve müzik eşliğinde karşılamauğurlama törenleri düzenlenmektedir. Ayrıca elçiler ve mahiyetlerindekilerin atları da değiştirilmektedir (Uyar, 2012, s. 84). Elçilerin karşılanma usulleri ile ilgili bilhassa Rubruk ve Carpini'nin notları da kıymetlidir. Carpini bu konuda "diğer ülkelerden vergi getiren veya elçi olarak gelen kimselere de at, araba ve iaşe vermek zorundadırlar" şeklinde bir kayıt düşmüştür (2000, s. 69). Elçilerin ihtiyaçlarının karşılanması ile ilgili benzer kayıtlar Rubruk'un seyahatnamesinde de mevcut olup, kendileri ile ilgilenmek üzere bir görevli tayin edildiği, soğuk mevsim geçinceye kadar iki ay boyunca istedikleri yerde konaklamak üzere bütün ihtiyaçlarının karşılanacağı belirtilmektedir (2001, s. 87). Carpini ise elçilerin hepsine aynı ölçüde davranılmadığına da vurgu yaparak doğrudan Moğol hükümdarına elçi olarak gelmeyen kişilerle yeterince ilgilenilmediğine, onlara az yiyecek, içecek, giyecek sunulduğuna değinmektedir (2000, s. 69).

Ayrıca Moğolların elçilere tercüman tayin ettiklerini görmekteyiz. Carpini, Batu'nun huzuruna çıktıklarında tercümanların görevlendirildiklerini ve getirdikleri mektubun Rusça, Arapça, Türkçe ve Moğolcaya çevrildiğini ve Moğolca çevirinin Batu'ya verildiğini belirtmektedir (2000, s. 111). Gelen misyonların getirdikleri mektupların tercüme edilebilmesi için gerektiğinde heyet öncelikle bu işin yapılabileceği bir yere götürülmekteydi. Bu kapsamda Batu Han'ın bulunduğu merkezin yeterli insan kaynağına sahip olduğu söylenebilir. Çünkü 1246 yılında gelen dört rahip hudut kumandanının huzuruna çıkarılmış, Papa'dan getirdikleri mektubun Latince olduğu anlaşılınca otuz dokuz günlük bir yolculukla Batu Han'ın sarayına götürülmüşlerdir. Getirdikleri mektup ise Moğolca, Rusça ve Arapça dillerine tercüme edilmiştir (D’ohsson, 2014, s. 227-228).

Carpini elçilik görevini tamamladıktan sonra Batu'nun sol tarafına oturduklarını, uzaklardan gelen elçilerin bu şekilde yapmak durumunda olduklarını belirtmektedir (2000, s. 112). Burada aktarılan bilgide elçi kabulünde belirli bir uygulamanın olduğuna işaret edilmektedir.

Carpini, Güyük'ün Moğolların büyük hanı olarak seçildikten sonra huzura kabulleri hakkında ayrıntılar vermektedir. Huzura kabul edilen bütün elçilerin isimleri ile yüksek sesle çağrıldıktan sonra dizlerini dört kez yere vurduklarını, muhafızlar tarafından arandıktan sonra Güyük Han'ın çadırına doğu kapısından girdiklerini ifade etmektedir. Ardından elçilerin getirdikleri ipek, kumaş, kürk, işlemeli kemer vs. gibi hediyeleri takdim ettiklerini belirtmektedir (2000, s. 125-126). Anselm, Simon, Albert ve Aleksandr'ın getirdikleri mektuba karşılık Güyük Han'ın cevabı yazılmadan evvel rahiplere Papa'nın sarayında Moğolca, Rusça veya Arapça bilen olup olmadığı sorulmuş, rahipler bu dilleri bilen olmadığı yanıtını verdikten birkaç gün sonra imparatorluğun önemli devlet adamla- 
rından Çinkay ${ }^{4}$ ve Bela cevabı bizzat yazdırmak üzere rahiplerin yanına gelmiştir. Güyük Han’ın cevabı rahipler tarafından Latince olarak yazıldıktan sonra söylenen her ifadenin iyi anlaşılıp anlaşılmadığı da sorulmuştur (D’ohsson, 2014, s. 229). Devlet bünyesinde pek çok kâtibin yer almasına rağmen, mektubun yazdırııması için iki üst düzey Moğol devlet adamının bu işle görevlendirilmesi diplomasi anlayışı açısından son derece önemli bir husus olarak görülmektedir. Ayrıca mektubun yazılması ile ilgili Moğolca, Rusça ve Arapça üzerine geçen konuşma ise Moğol devlet kademesinde birkaç dil bilen devlet yetkililerinin olduğunu göstermektedir. Carpini'nin kabulünde olduğu gibi ondan bir süre sonra Moğol hanı Möngke'nin huzuruna çıkan Wilhelm Von Rubruk'un kayıtlarında da Moğol idarecilerin ve hanın yanında tercüman bulundurduğu belirtilen bir durumdur (2001, s. $86,87)$. Hanların yanında tercüman bulunması hususunu Roux bir mecburiyet olarak telakki etmektedir. Çünkü Moğol idareciler sadece yönettikleri askerlerle değil, memurlarla, dini cemiyet önderleriyle, bölge valileriyle, generallerle, elçilerle ve görüşmede bulundukları devletlerin başındakilerle de iletişim kurabilmeliydiler. Dolayısıyla imparatorlukta ve prenslerin çevresinde yalnızca birkaç dil bilmeleri sebebiyle saygı gösterilen her türlü serüvencinin bulunduğuna işaret edilmekte$\operatorname{dir}$ (Roux, 2001, s. 243, 244). Bu ve benzeri kayıtlar Moğolların diplomasi kabiliyeti açısından önemli bir husustur.

Son olarak Moğolların elçilikle ilgili işlerin takip edilmesinde devlet mekanizmasında bir birim teşkil ettiklerini de belirtmek gerekir. Özellikle Altın Orda Devleti'nin batı ile münasebetleri çerçevesinde kaleme alınan bazı evraklarda bu tespite dair çıkarımlarda bulunmak mümkündür. Bu kapsamda Berdibek Han'ın Azak'ta faaliyette bulunan Venedikli tüccara verdiği 24 Eylül 1358 tarihli yarlı̆̆ın başında geçen “...Moğol Devleti'nin (Altın Orda) bütün tümen beylerine, binbeylerine, yüzbeylerine ve onbeylerine, iç şehirlerin daruga beylerine, devlet kançılaryasının görevlilerine ve yine birçok gezgine ve seyyaha, her türlü idareci, elçi ve habercilere, gümrükçü ve tartnakçılara, karavul ve tutkavullara sözümdür" (Özyetgin-Kemaloğlu, 2017, s. 123) şeklindeki ifadeler önemlidir. Buradaki terimler ele alındığında elçi ve konsoloslarla ilişkili olan ve bunların bağlı olduğu idare anlamında kullanılan devlet kançılaryası kavramı dikkat çekmektedir ve buradan hareketle dış ilişkilerin yürütülmesinde özel bir birim oluşturulduğu söylenebilir. Söz konusu kayıtlar yukarıda Çinkay ile ilgili verilen bilgilerle de örtüşmektedir. Bu birimin de bir şekilde Moğol İmparatorluğu'ndaki posta teşkilatı ile bağı söz konusu olmalıdır.

\footnotetext{
${ }^{4}$ Çinkay’ın Çingiz Han zamanında Moğol imparatorluğunun elçilerle ilgili işlerinin işleyişinden sorumlu olduğu, ayrıca onun bilgisi ve muvafakati olmadan devlet içinde imparator emri çıkmadığı, herhangi bir vesikanın da yine Çinkay'ın onay yazısıyla tamamlanabildiği Ligeti tarafından ifade edilmektedir (2011, s. 113-114). Aslen Uygur olan Çinkay, Taoist rahip Chang Ch'un'un seyahatnamesine göre Moğolların Harezm seferinin sürdüğü günlerde bürokrasinin içine girmişti (Özcan, 2013, s. 158). Onun geniş yetkileri Ögedey Kağan zamanında da devam etmişti. Möngke'nin hükümdarlığının ilk yıllarındaki isyana karıştığından 1252 yılında diğer asilerle birlikte ortadan kaldırımıştır (Ligeti, 2011, s. 113-114).
} 
Oktay BERBER

\section{Elçilerin Seyahatinde Posta Teşkilatının (Yam Sisteminin) Önemi}

13. yüzyılın ilk yarısında Moğol İmparatorluğu elçilerinin hareketlerinin daha önce bir bozkır devletinde görülmemiş derecede iyi olduğu ifade edilmektedir. Elçilerin bu hareketliliğinde imparatorluk boyunca yer alan yam sistemi adıyla bilinen posta teşkilatının yeri son derece mühimdir (Ver, 2011, s. 111). Ögedey zamanında oluşturulan posta teşkilatı (yam sistemi) hakkında Moğolların Gizli Tarihi'ndeki kayıtta bu sistemin amacı açık bir şekilde ifade edilmiştir. Ögedey Kağan babasının yerine tahta oturduktan sonra yaptığı işleri anlatırken ikinci sırada bu teşkilattan "aramızda elçi yollayıp ilişki kuracak ve çok çeşitli gerekleri taşıyacak han yolu koydurdum" şeklinde bahsetmektedir (2011, s. 250). Sistemin kurulma amacı ile ilgili Cüveynî de "ülke büyüyüp genişlediği zaman düşmanlar, olaylar ve çeşitli hadiselerle ilgili haberleri göndermek, ayrıca batıdan doğuya, doğudan batıya doğru yollardan geçen malları ve eşyaları korumak düşüncesi posta menzilleri (yam) kurulmasına sebep oldu" şeklinde kayıt düşmektedir (Cüveynî, 1999, s. 92). Bu gibi ifadelerden posta teşkilatının devletlerarası ilişki ve güvenlikle ilgili hususlarda önemli olduğu sonucuna varılabilir.

Yam sistemi aslında Moğollar tarafından daha önceden bilinmekteydi. Özellikle Soğdlar ve Türkler tarafından erken Ortaçağ'da posta hizmetlerinin kullanıldığı ifade edilmektedir. Moğol idareciler de Çin, Hindistan, Orta Asya, İran ve Deşt-i Kıpçak gibi alanlarla iktisadî ilişkileri arttırmak için ticaret yollarına ve posta teşkilatına önem vermişlerdir (Kalan, 2015, s. 97). Böylelikle Moğol idaresi bu sistemi geliştirmiş ve döneminin en hızlı ulaştırma olanağı haline dönüştürmüştür. Hızlı haberleşmenin düşmanlara karşı da ciddi bir avantaj sağladığını ifade etmek gerekir. Bir bakıma Moğol fetihlerinin başarıya ulaşmasında sistemin iyi işleyişi etkili olmaktaydı.

13. yüzyılda içerisinde yedek atların tutulduğu ahırlar, atların beslenmesi için arpa ve burada kalan kişinin dinlenip yemek yiyebileceği menzillere yam adı verilmekteydi (Kalan, 2015, s. 97). Bu nedenle oluşturulan posta teşkilatına yam sistemi de denilmektedir. Bu teşkilat Merkez Moğolistan'dan Çin'e ve batıda Aşağı Volga'ya kadar uzanmaktaydı. Bu büyük sistem imparatorluktaki bilgi akışını da sağlamaktaydı. Posta istasyonları üç biçimdeydi. Morin ${ }^{5}$ denilen at istasyonları, özellikle elçiler, resmi yetkili veya memurlar olmak üzere seyahat eden insanlar içindi. Narin denilen idare istasyonları Moğolların büyük hanı ile doğrudan iletişim sağlamak içindi. Tergen ${ }^{6}$ denilen vagon istasyonları ise yiyeceklerin taşınması amacıyla oluşturulmuştu. Elçiler her yedek istasyonda atlarını değiştirebilmekteydi. Böylelikle varacakları noktaya kadar durmadan ilerleyebiliyorlardı. Elçiler bazen çok önemli mesajlar iletmek için de gönderilmekteydi. Örneğin Marco Polo Moğol kağanının mesajlarının iki gün ve gecede bir istasyondan diğerine aktarılmak suretiyle on günden daha az bir sürede iletildiğini kaydetmektedir. Seyahat eden kişiler imparatorluk arazisi boyunca geçerli olan ve bilgilerinin yer aldığı payza adı verilen bir nevi kimlik taşımaktaydılar (Ver, 2011, s. 112). Habercilere

\footnotetext{
${ }^{5}$ Morin kelimesi Moğolcada “at” anlamına gelmektedir (Lessing, 2017, s. 664).

${ }^{6}$ Burada verilen anlamına uygun olarak tereg, tergen kelimeleri Moğolcada "araç, taşıt; araba, yük arabası, vagon, taşıma aracı; araba, otomobil” anlamlarına gelmektedir (Lessing, 2017, s. 956).
} 
ve yüksek devlet memurlarına verilen bu kimlikler kimin emriyle yolculuk yapıldığı, devlet işlerinde bu kişilere kolaylık tanınması gibi hususlarda kullanılmaktaydı (Dayı, 2015, s. 243; Marshall, 1996, s. 46). Ayrıca taşınan bu kimliğin birkaç çeşidi olduğunu belirtmek gerekir. Peng Da Ya ve Xiu Ting'in kayıtlarında Moğollarda kaplan kafalı altın payza ${ }^{7}$, düz altın payza ve düz gümüş payza olmak üzere üç çeşit payza olduğu ifade edilmektedir (Uyar, 2012, s. 131).

Rahipler başta olmak üzere doğuya seyahat eden kişilerin Moğol İmparatorluğu sınırlarına girdikleri andan itibaren Moğol muhafızlar tarafından kendilerine eşlik edildiği, böylelikle tehlikelere karşı korundukları ifade edilmektedir. Ayrıca Moğollara gönderilen elçilerin korunması ve ihtiyaçlarının karşılanması gönderen tarafından talep edilen de bir husustur. Örneğin Papa IV. Innocentius, Moğol ülkesine gönderdiği Carpini'ye verdiği 5 Mart 1245 tarihli mektupta "elçilerimizin başına bir bela gelmeden gidiş ve dönüşlerini emniyet altına alın ve iaşe için gerekli olan şeyleri verin" diyerek talebini Moğol yetkililere iletmiştir (2000, s. 19).

Posta teşkilatının Moğollara gönderilen elçilerle ilk temasın sağlandığı ve onları gerekli yerlere götürmekle sorumlu oldukları ile ilgili olarak Papa'nın mektubunu Illhanlılara iletmek üzere 1246 yılında yola çıkan heyete dair yaklaşım gösterilebilir. Lombardiyalı Anselm, St. Kentenli Simon, Albert ve Aleksandr isimli rahiplerden oluşan bu heyet Kiev'den ayrıldıktan altı gün sonra Moğolların hudut posta kollarına ulaşmışlar ve posta kolu bu kişileri hemen kumandanın huzuruna götürmüştür (D’ohsson, 2014, s. 227). Moğol idarecilerin bu şekilde gelen kişileri koruma altına almaları ve onlara eşlik edilmesinin önemli bir sebebi olarak imparatorluk sınırlarına giren kişilerin Moğol ordusu hakkında ayrıntılı bilgi edinmelerinin önüne geçmek olduğu ileri sürülmektedir (Ver, 2011, s. 111). Bu konuda da Carpini'nin seyahatnamesindeki "amacımız en azından Moğolların gerçek niyet ve planlarını ögrenip, bunları Hıristiyanlara bildirerek, ani bir saldırı durumunda, geçmişte olduğu gibi hazırlıksız yakalanmalarını önlemeyi sağlamaktı (2000, s. 24)" şeklindeki ifadeler önemlidir. Çünkü söz konusu satırlar bir bakıma ülkeye gelen elçilerin gözlem yapma amaçlarını da ortaya koymaktadır.

Posta teşkilatı Moğollara gelen elçilerin güvenliğinin ve ihtiyaçlarının karşılanmasının sağlanması için kullanıldığı gibi Moğol yöneticilerinin başka ülkelere gönderdikleri temsilcilerinde ihtiyaçlarını karşılamaktaydı. Hülagu'nun selefi olarak 1265 yılında tahta çıkan Abaka Han, Memlûklere karşı işbirliği arayışı içerisinde olmuştur. Bu doğrultuda babası Hülagu döneminde olduğu gibi batı ile ittifak yapmak istemiştir. Illhanlı tahtındaki ilk yılında müzakereler yapmak ve ittifak kurmak için Papa IV. Clemens'a bir elçilik heyeti göndermiştir. Gönderilen elçilik heyetinin tarihi ile ilgili olarak Moğolca belgede "tavşan ylı" ifadesi geçtiği, bunun da Abaka Han dönemindeki 1267 ve 1279 yıllarına karşııı geldiği ifade edilmektedir. Her ne kadar tarihsel olarak net bir saptama yapılamasa da belgenin içeriğinde geçen ifadeler elçilere verilen önemi yansıtmaktadır. Söz konusu belgede

\footnotetext{
7 Altın payza konusunda Kazvinî "üzerinde arslanın başı resmedilmiş bu payize, en kıymetli madalyaydı" şeklinde açıklama yapmaktadır (Cüveynî, 1999, s. 13)

${ }^{8}$ Belge metni Ek-2'de verilmiştir.
} 
Oktay BERBER

elçinin geçtiği yerlerdeki vali, kumandan, posta istasyonu yetkililerine, ulaşım için görevli herkese elçilerin ihtiyaçlarının karşılanması ve sahip oldukları eşyaların kesinlikle ellerinden alınmaması hususlarında Abaka'nın emri yer almaktadır (Mostaert-Cleaves, 1952, s. 430-432, 433-434).

Seyahat eden kişilerin güvenliğini sağlamak açısından yam sisteminin önemi ve gerekliliği 14 . yüzyılda da devam eden bir durumdur. Delhi'ye Çin'den gelen elçilere karşılık Çin'e giden kalabalık heyete dâhil edilen İbn Battûta da bu hususa önemle vurgu yapmaktadır. Battûta, Çin'de her konak yerinde bir han bulunduğunu, burada bir grup görevli askerin beklediğini, her akşam handa konaklayan kişilerin isimlerinin yetkili bir kişi tarafından kaydedildikten sonra han kapısının kilitlendiğini, ertesi sabah herkesle tek tek görüşülerek bilgi alındığını kaydetmektedir. Bu işlem tamamlandıktan sonra da seyahat eden kişilerin yanına diğer konaklama noktasına kadar eşlik etmek üzere adamlar verildiğini, görevlilerin bu kişileri ulaştırdıklarına dair belgeyi mutlaka bir önceki konaklama noktasına getirmekle yükümlü olduklarını ifade etmektedir. Battûta bu sistem sayesinde bir kişinin bütün servetiyle dokuz aylık bir güzergâhı hiç kaygılanmadan tek başına gidebileceğine dikkat çekmektedir (Battûta, 2000-II, s. 899).

\section{Mektuplardaki Diplomasi Dili}

Çingiz Han'dan itibaren bir takım kayıtlar üzerinden Moğol idarecilerin diplomasi diline dair bazı çıkarımlarda bulunmak mümkündür. Benzer şekilde elçiler vasıtasıyla diğer devletlerden gelen mektuplarda da Moğollara karşı yaklaşım tespit edilebilmektedir. Örneklerde görüleceği üzere, içinde bulunulan şartlar Moğolların ve muhatabı tarafın birbirine hitap ve yaklaşımına etki eden en önemli faktörlerden biridir.

Mektuplarda kullanılan ifadelere dair Çingiz Han dönemine ait bilgi söz konusudur. Harezmşahların hükümdarı Sultan Muhammed Buhara'da bulunduğu sırada Çingiz Han tarafından gönderilen elçiler hanın mesajını hükümdara iletmişlerdir:

"Size selam ederim, imparatorluğunuzun genişliğini biliyor ve sizinle dost olmayı arzu ediyorum. Size oğullarımın en mümtazı nazarıyla bakacağım. Elbet siz de biliyorsunuz ki, ben Çin'in bir kısmına hükümranım ve kuzey tarafındaki kabileler hep benim idaremdedir. Büyük gümüş madenleriyle, karıncalar kadar çok cengâver ile bir imparatorluğa sahip olan ben, başka yerlere göz dikmeye muhtaç değilim. Fakat tebaalarımız arasında ticareti kolaylaştırmak için sizinle bir ticaret anlaşması yapmak, her ikimizin de menfaatine uygundur sanırım." (D'ohsson, 2014, s. 93)

Çingiz Han'ın buradaki ifadelerinde diplomasi dili açısından önemli hususlar mevcuttur. Öncelikle Çingiz Han, Harezmşahlara karşı herhangi bir düşmanlık hissine sahip olmadığını açıkça ifade etmekte ve bunun bir yansıması olarak kendileriyle iktisadî bağlar kurmak istediğini dile getirmektedir. Çingiz Han'ın özellikle Moğol İmparatorluğu'nun kalkınması ve ekonomik olarak güçlü olabilmesi için Harezmşahların elindeki önemli ticaret merkezleri ile bağ kurmanın gerekliliğinin farkında olduğunu belirtmek gerekir. Bu ihtiyaca mukabil Çingiz Han'ın ve devletinin de bir acizlik veya 
muhtaçlık durumu olmadığı açık bir şekilde ifade edilmektedir. Ifadelerde geçen bir başka husus ise Çingiz Han'ın gücünü tarif etme biçimidir. Bir yandan kendi gücünü vurgularken diğer yandan Harezmşahlar da küçük görülmez ve devletlerinin genişliğine vurgu yapılır. Ancak burada önemli noktalardan biri Çingiz Han'ın karşı tarafın gücüne saygı gösterirken kendi konumu ve otoritesinin daha üstün olduğunu belirtmesidir. D’ohsson da "oğlum, küçük kardeşim, yeğenim" gibi ifadelerin zamanın siyaset dilinde emirlere karşı kullanıldığını ifade etmektedir (2014, s. 93). Sultan Muhammed'e "oğlum" sıfatıyla hitap ederken Çingiz Han sahip olduğu konumu diplomatik olarak ifade etmiş olmaktadır.

Kendisine karşı kullanılan ifadeden rahatsız olan Sultan Muhammed ise, Çingiz Han'ın elçilerinden Mahmud'u çă̆ırtarak neden bu şekilde bir ifade kullandığını, kendi gücü ile Çingiz Han'ın kuvvetleri arasında nasıl bir fark olduğunu sormuştur. Elçi Mahmud'un Çingiz'in gücünün fazla olduğunu belirtmesi üzerine ona hitaben dostça ifadelerle bir mektup yazarak elçilerini geri göndermiş̧ir (D’ohsson, 2014, s. 94).

Fransa kralının elçisi olarak 1253 yılında yola çıkan Fransisken rahibi Wilhelm Von Rubruk'un kayıtlarında Moğolların hanı Möngke'nin sarayında bulunan elçiler hakkında bilgi söz konusudur. Rubruk Möngke'nin bulunduğu yerde Mons Regalis ve Krak (Montreal) hükümdarlarından gelen Dimaşklı bir elçi olduğunu kaydetmektedir. Daha önce de Akka'dan bir ruhaninin oraya nasıl geldiğinden bahsedilmektedir. Ayrıca Rubruk'un seyahatnamesinde Möngke Han’ın Frank hükümdarı Kral Malek'e gönderilmek üzere bir elçilik heyeti tesis edilmesi söz konusudur. Elçilik heyetinde Kral Malek'in gönderdiği Theodolus adlı kişi ile birlikte birkaç Moğol da görevlendirilmiştir. Möngke'nin altın bir fermanı verilerek tabilerinden fermanı taşıyan kişilerin bütün isteklerinin yerine getirilmesi emredilmiştir. Möngke Han Theodolus ile birlikte görevlendirdiği Moğollara söylediği "Bu adamla beraber Frank kralına gideceksin ve benim maksadımla bu şeyleri (yay ve uçları gümüş iki ok) ona vereceksin. Eğer o, bizimle barış yapmak istiyorsa, kendi sınılarına kadar Müslümanların ülkesini zapt edeceğiz ve batıda kalan diğer ülkeleri ona vereceğiz. Fakat, bunu istemiyorsa, bu yayla okları çok uzaklara kadar fırlatacağımızı anlattıktan sonra, yayı ve okları geri getir’(Rubruk, 2001, s. 90) şeklindeki ifadeler diplomasi dili açısından son derece önemlidir.

Bilindiği üzere yay ve ok bilhassa Türk devlet teşkilatında olmak üzere bozkırda önemli hâkimiyet sembolleridir (Turan, 1945, s. 306 vd; Göksu, 2010, s. 987 vd). Nitekim Aknerli Grigor da okun Moğol tarihi açısından önemini yazdığı eserin ismi ile ifade etmek suretiyle Moğollar için "okçu millet" tabirini kullanmıştır (Grigor, 1954). Dolayısıyla Möngke Han da buradaki ifadeleriyle Moğol askerlerinin ulaştığı her yerin kendisine tabi olacağını sembolik olarak ifade etmiştir.

Daha sonra Möngke Han, Fransa Kralı Ludwig'e iletilmek üzere bir mektup yazarak Rubruk'a teslim etti. Mektup içerisinde yer alan “...ebedî Tanrı́nın kudretiyle dünya güneşin doğduğu yerden battığı yere kadar neşe ve barış içinde olacaksa, işte bizim yapmak istediğimiz şey gerçekleşmiş olacaktır" şeklindeki sözleri de Möngke'nin gücünü batıya gösterme şeklidir. Ayrıca "bizim ülkemiz uzaktadır ve yüksek dağlar bizi korur ve denizimiz de büyüktür' buna güvenerek sakın bize karşı 
Oktay BERBER

ordu göndermeyin, zira biz ne yapacağımızı biliriz" şeklindeki ifadelerle de Moğolların Fransa'ya kadar gidebilecek güçte olduğu konusunda Fransa kralı uyarılmaktadır (Rubruk, 2011, s. 128).

Çingiz Han'ın Büyük Moğol Devleti'ni kurarken elde ettiği toprakların çok büyük bir bölümünde bölge insanı ve yönetimleri açısından felaketle sonuçlanan askerî faaliyetlerde bulunduğu, bu sebeple Moğol idaresinin gayri medeni bir yaşam sürdüğü pek çok çalışmada dile getirilmektedir. Özellikle son dönemlerde ortaya konulan çalışmalar vasıtasıyla bu görüşün hatalı olduğu, Moğol devletinin ve idarecilerinin teşkilatlı bir yapıya sahip oldukları, elde ettikleri topraklarda yüzyıllar boyunca devam edecek kültürel ve siyasal etkiler bıraktıkları ortaya konulmaktadır. Ele alınan konu açısından bu noktada belirtmek gerekir ki, yıkıcı olarak nitelenen Moğol fetihlerinin yapılmasının sebepleri arasında diplomasinin hiçe sayılması önemli bir etkendir. Özellikle Moğolların büyük hanı Güyük'ün Papa IV. Innocentius'a iletilmek üzere elçi Carpini'ye verdiği mektupta bu husus "...mektubunda insanları, özellikle daha çok Macaristan, Polonya ve Morovya'daki Hıristiyanları kılıçtan geçirmemizin seni üzdüğünü ve hayrete düşürdüğünü yazmaktasın... (Bunu yaptık) çünkü, onlar Tanrı́nın Çingiz Han'ın yasalarına uymayıp, önceden planladıkları şekilde kötü kalpleriyle elçilerimizi öldürmüşlerdir. Bu nedenden dolayı Tanrı bize onları ortadan kaldırmayı emretmiş ve kaderlerini ellerimize bırakmıştır..." şeklinde açıkça ifade edilmektedir (2000, s. 21; Dawson, 1955, s. 85).

Moğol hanlarının devletin sahip olduğu konumu ve gücü ifade etmeleri diplomasi anlayışı içerisinde önemli bir yer tutmaktadır. Hülagu'nun Memlûk Devleti Sultanı Seyfettin Kutuz'a gönderdiği mektupta da bu durum açıkça görülmektedir. Hülagu'nun elçileri Kahire'ye ulaştıktan sonra 21 Ocak 1260 tarihinde mektubu sultana sunmuşlardır (Sağlam, 2018, s. 86). Reşîdüddin Fazlullah'ın Câmiu't-Tevârih adlı eserinde geçen ifadelerde Hülagu'nun üstün olduğu ifade edilmektedir:

"Yüce Tanrı, Çingiz Han ve onun uruğunu güçlendirip, yeryüzündeki memleketlerin hepsini birden bize bağışladı. Her kimse ki bizim itaatimizden ve bize tabi olmaktan baş çevirdiyse, karısı, çocukları ve kendisi ve ona tâbi olan kimseler ve beldeleri yok oldu. Her halde bunlar sizin kulağınıza ulaşmıştır. Sınırsız olan askerimizin ünü, Rüstem ve İsfendiyar destanı gibi şöhret bulmuştur. Eğer bizim hazretimizin kullarına boyun eğiyorsan mal (vergi) gönder, kendin gel ve şıhne iste, yoksa savaş için hazırlan." (Fazlullah, 2013, s. 55-56).

Gönderilen mektubun ardından Hülagu, Moğol Büyük Hanı Möngke Han'ın ölümü sebebiyle yapılacak hanlık seçimi sebebiyle bölgeden ayrılmıştır. Onun ayrılması ardından savaş kararı alan Sultan Kutuz da İlhanlı elçilerinin başlarını vurdurtmuş ve kale kapısına astırtarak Hülagu'ya çok sert karşılık vermiş oldu. illk İlhanlı diplomatik girişiminin başarısızlıkla sonuçlanması ardından 3 Eylül 1260 tarihinde gerçekleşen Ayn Câlût Savaşı'nda Moğollar yenilmiştir (Sağlam, 2018, s. 88).

Mektuplardaki ifadelerden Moğol idaresinin diplomasiye ve elçilik makamına ne kadar önem verdiğini tespit etmek mümkündür. Ayrıca askerî bir seferden önce diplomasinin söz konusu oldu- 
ğunu, diplomasinin geçersiz olduğu veya yok sayıldığı durumlarda askerî sefer sürecinin başladığını söylemek mümkündür.

Ayrıca Ayn Câlût Savaşı sonrasında Batının muhatabı konumundaki illhanlı yöneticilerinin uzlaşmaya kapalı görünen diplomasi tarzının değişmesi söz konusu olmuştur. Özellikle Memlûklerin uluslararası alanda illhanlılara karşı başarılı bir politika yürütmeleri ve Baybars'ın savaş sonrasındaki süreci iyi idare ederek attığı stratejik adımlar İlhanlıların yalnızlaşmasına sebebiyet vermiştir. Dolayısıyla İlhanlı yöneticileri mevcut duruma gerektiği gibi cevap verememeleri diplomasi anlayışlarının değişimini zorunlu kılmıştır (Türker ve Karaduman, 2018, s. 730, 733).

\section{Diplomaside Hediyeleşme}

Hediyeleşme diplomaside önemli bir uygulama ve ritüel olarak yerini almış olup bozkırda yaygın olarak Türkler tarafından da kullanılmaktadır. Kimi zaman iki taraf arasındaki ilişkilerin savaştan barışa geçişine de vesile olduğunu belirtmek gerekir. Temeli diplomatik mektuplaşmaya dayanan bu sisteme dair 13. yüzyıldan 15. yüzyıl sonlarına kadarki dönem için Fars, Arap, Çin kaynaklarına dayalı anlatımların olduğu ifade edilmektedir (Yihao, 2016).

Hediyeleşme kültürüne dair Çingiz Han dönemi üzerine Harezmşahlarla ilişkiler değerlendirilebilir. Harezmşahların hükümdarı Sultan Muhammed Buhara'da bulunduğu sırada Çingiz Han tarafından gönderilen elçileri kabul etmiştir. Elçiler gümüş külçeleri, keçi, yeşim taşı, tarkul denilen ak yün elbiseden oluşan hediyeleri Sultan Muhammed'e takdim ettiler (D’ohsson, 2014, s. 93). Gerçekleşen bu girişimden sonra iki tarafın ticarî ilişkilerde bulunmak üzere anlaştığı ifade edilmektedir. Hatta Çingiz Han ticaret yapmaları için altın, gümüş, ipek, turgu denilen kırmızı renkli bir çeşit iplik ve nadide bir takım eşyalarla yüklü beş yüz deve göndermiştir. Ancak Çingiz Han’ın gönderdiği bu heyet Otrar'da alıkonulmuş ve öldürülmüştür. İçlerinden yalnızca bir kişi kaçarak Çingiz Han'a olanları anlatmıştır (el-Cüzcânî, 2015, s. 136). Bunun üzerine Çingiz Han Bagra (Toh-togan) adındaki Türk elçisini iki Moğol ile birlikte gönderdi. Sultan Muhammed'den cezalandırımak üzere Otrar Valisi'nin kendisine teslim edilmesi istenmiş, fakat Sultan Muhammed bu isteği geri çevirip, elçi Bagra'yı öldürtmüş, onları aşağılamak amacıyla elçinin yanındaki iki Moğol'un sakalını keserek Çingiz Han'a geri göndermiştir (Dohsson, 2014, s. 95). Kimi araştırmacılar tarafından Otrar faciası olarak adlandırılan, Harezmşahların yıkılmasına ve Türkistan'ın pek çok yerinin Çingiz Han'ın idaresine geçmesine sebebiyet veren askerî seferleri de bu şekilde başlamıştır. Seferin konumuz açısından önemi Moğol idarecilerin elçilerine verdikleri değer ile ilgilidir. Devleti temsilen elçiye yapılanlar bir bakıma devleti yönetene de yapılmış sayılmakta ve bu tip davranışlar uluslararası problemler oluşturabilmektedir. Nitekim bu kural günümüz diplomasi anlayışı açısından da geçerliliğini koruyan bir husus olarak görülmektedir.

Moğolların elçi olarak ülkelerine gelen kişiden hediye beklediklerine dair kayıtlar söz konusudur. Hatta Carpini, ünlü bir hükümdarın elçisi olarak yollanan kişiden daha fazla hediye beklentisi olduğunu da eklemektedir (2000, s. 69). Elçilerin hediye getirme âdetini 1246 yılında yola çıkan dört Fransisken rahibe dair örnekte de görebiliriz. Moğol hanına ulaşmak üzere yola çıkan bu misyon hanın huzuruna hediye ile gidilmesi gerektiğini yolda öğrenmiş̧ir. Ancak verilen sadakalar ile 
Oktay BERBER

geçindiklerinden böyle bir imkânları olmadığı için Lanciscia (Lansisk) Dükü Konrad ile Başpapaz ve Polonya'daki zenginler Moğollara hediye edilmek üzere rahiplere kürkler vermiştir (D’ohsson, 2014, s. 227).

Diplomatik görüşmelerdeki hediye geleneğine dair bir diğer örnek ise Yuan Hanedanlığı elçilerine ait kayıtlarda geçmektedir. Örneğin Yang Tingbi 1283 yılındaki Kollam ziyaretinde imparatorluk hediyesi olarak yay ve oklar, eyerler ve bir dizgin götürmüştür (Sen, 2006, s. 308). Hediye geleneğinin daha sonra da devam ettiği konusunda İbn Battûta'nın kayıtlarına bakılabilir. Battûta Yuan Hanedanlığı temsilcilerinin 1340 yılında Delhi'ye ulaştıklarında beraberinde 100 köle ve cariye, farklı şehirlerde üretilen kemha isimli beş yüz top ipekli kumaş, misk kokusu, inci işlemeli beş kat giysi, beş adet simli okluk ve beş adet kılıç getirdiklerini kaydetmektedir (2000-II, s. 758).

\section{Diplomatik Evlilikler}

Tarih boyunca pek çok devlet uluslararası ilişkilerinde özellikle siyasi ve iktisadi hedefleri sebebiyle bir başka devletin yönetici ailesine mensup kişilerle evlilik bağı kurmaktaydı. Diplomatik evlilikler olarak nitelendirilebilecek bu uygulama bozkırda da geçerliliğini koruyan bir unsurdu. Nitekim Batı Han Hanedanlığından (MÖ 206-MS 24) beri Çinli yöneticiler imparator ailesinden bir prensesi sınırlarındaki bozkırlı uluslarla evlendirmekteydi. $\mathrm{Ho}-\mathrm{ch}^{\prime} \mathrm{in}^{9}$ olarak ifade edilen bu uygulama ile Çin devleti güçlü bozkırlı uluslarla barış dönemi yaşayabilmekteydi. Çin'de Song İmparatorluğu'na son vererek Yuan Hanedanlığını tesis eden Kubilay Han da bu hanedanlığı evlilik ilişkisi ile oluşturmuştur (Zhao, 2008, s. 31).

Diplomatik evlilik geleneği yalnızca doğu devletlerine ait bir uygulama olmayıp batıdaki devletlerde de söz konusuydu. Doğu Roma yönetimi 13. ve 14. yüzyıllarda Ortadoğu coğrafyası ve Anadolu'daki siyasi kargaşa nedeniyle yabancı devletlerle evlilik pratiğinin genişletilmesini zorunluluk olarak görmüş, sonuçta İlhanlı ve Altın Orda devletleriyle bu türden bir ilişki tesis etmiştir. Böylece daha öncesinde Doğu Roma kadınlarının Hıristiyan batı krallıklarına gönderilmesi ile oluşturulan standart diplomasi pratiği Hıristiyan olmayan doğu ile de gerçekleştirilmeye başlanmıştır (Weller, 2016, s. 178-179). Ancak bu dönemde illhanlı Devleti ile Altın Orda Devleti arasındaki ilişkiler iyi değildi. ${ }^{10}$ Bu sebeple VIII. Michael'in dış politikada ikili oynadığını ifade etmek gerekir. Bu doğrultu-

\footnotetext{
${ }^{9}$ Büyük Hun Devleti hükümdarı Mo-tu ile ilgili olarak Han Shu'da ho-ch'in adı verilen evlilikle ilgili pek çok kayıt söz konusudur. Bu kayıtlar incelendiğinde evliliğin bir tür anlaşma olduğu da görülmektedir (Onat vd., 2004, s. 12 vd). Benzer uygulamaya Kök Türk Devleti döneminde de rastlanmaktadır (Taşağıl, 2013, s. 58).

${ }^{10}$ Batu Han'ın ölümüne kadar Anadolu ve Azerbaycan toprakları üzerinde Altın Orda Deveti'nin hakları söz konusuydu. Batu Han'ın ölümünden sonra Altın Orda tahtında ortaya çıkan iktidar boşluğu İlhanlı Devleti'nin kurucusu Hülagu'nun Altın Orda'ya karşı yükümlülüklerini yerine getirmemesine sebep olmuş, Berke'nin Altın Orda tahtına geçtiği 1256 'dan sonra da iki devlet arasındaki ilişkiler bozulmuştur. İlişkilerin bozulmasında Hülagu'nun Altın Orda Devleti'nin Azerbaycan üzerindeki haklarını tanımayarak Tebriz şehrini İlhanlı başkenti olarak ilan etmesi, Azerbaycan'daki Altın Orda memurlarının bir kısmının öldürülmesi ve bir kısmının kovulması, tüccarın mallarını yağmalatması ve Altın Orda taraftarlarını bölgeden uzaklaştırmasına karşın Berke Han'ın da benzer şekilde Deşt-i Kıpçak'taki İlhanlı
} 
da 1260 yılında İlhanlılar ile İznik'te bir antlaşma imzalanmıştır. Bu antlaşma ile Hülagu Han Anadolu Selçuklularına karşı daha serbest hareket edebilmiştir. Ardından 1262 yılında i̇stanbul Pantokrator Manastıı başpapazı Prinkips başkanlığında bir heyet Hülagu Han'a gönderilmiştir. Görüşme neticesinde yapılan anlaşmanın gizli tutulduğu, böylelikle VIII. Michael'in Altın Orda ile de özellikle ticaret üzerinden iyi ilişkiler tesis ettiği görülmektedir (Kamalov, 2005, s. 3-4).

13. yüzyıldaki Moğol ilerleyişi neticesinde Doğu Roma İmparatorluğu kendi çıkarları için İlhanlı Devleti ile iyi diplomatik ilişkiler kurmak durumunda kaldı. Pachymeres, Anadolu'daki Moğol ilerleyişinin olduğu dönemde İlhanlı hükümdarının Palaiologoi ile evliliğinin Bizans ile Moğollar arasındaki düşmanlığın azaltılmasına ve Türkmenlerin baskı altına alınmasına vesile olduğunu kaydetmektedir. Ayrıca Pachymeres, bu tür evliliklere karşı ideolojik yasaklar olmasına karşın Anadolu'da Doğu Roma'nın gücünü koruması için bu türlü ittifakın gerekli olduğunu ifade etmektedir (Weller, 2016, s. 185).

İlhanlı Devleti ve Doğu Roma arasındaki ilk evlilik akdi 1264 yılında VIII. Michael Palaiologos'un gayri meşru kızı Mariya'nın Abaka Han ile evlendirilmesi ile gerçekleşmiştir. Aslında Mariya'nın Hülagu Han ile evlendirilmesi kararlaştırılmıştı. Ancak Mariya'nın Illhanlı başkentine ulaştığı sırada Hülagu Han'ın ölmesi sebebiyle evlilik akdi Hülagu'nun oğlu Abaka ile gerçekleştirilmiştir (Weller, 2016, s. 187). Bu noktada Doğu Roma ile İlhanlı arasındaki evlilik akdinin Michael'in gayrı meşru kızı ile gerçekleştirilmesi dikkat çekicidir. Öyle görünüyor ki, daha önce Pachymeres'e atıfla sözü edilen bu türlü evliliklere karşı var olan ideolojik yasaklar sebebiyle Doğu Roma yönetimi hanedan ailesi ile doğrudan bağı olmayan bir kadını Hıristiyan olmayan Illhanlılarla evlendirmiştir. Böylelikle evliliğe karşı Doğu Roma içerisinde ortaya çıkabilecek olası itirazlar da azaltılmak istenmiş olabilir.

VIII. Michael'in Hülagu Han ile gerçekleştirdiği evlilik akdinin sebepleri arasında Moğol topraklarında Hıristiyanlı̆ı̆n ve dolayısıyla Bizansılıaşmanın yayılmasının amaçlandığı ifade edilmektedir. Bunun için uygun bir zemin olduğu da düşünülmektedir. Çünkü Hülagu Han'ın ilk eşi Nesturî Hristiyan'dır. 1264 yılında İlhanlı ülkesini ziyaret eden Ermeni tarihçi Vardan Arewelc'e göre Hülagu Han da doğduğundan beri kendisinin Hıristiyan olduğuna inanmaktadır. Ayrıca Hülagu'nun batı krallarına yazdığı mektupta da bu durumun yansıtıldığı ifade edilmektedir. Weller, bu türlü ifadelerin Moğol diplomasi pratiğinin bir parçası olduğunu ve illhanlı ülkesinde Hıristiyan sempatisine mutlak bir dönüşümün söz konusu olmadığını belirtmektedir (2016, s. 187).

Moğollarla Doğu Roma arasında evlilik bağı ile gerçekleşen diplomatik ilişkilerin sürekli olmadığını ifade etmek gerekir. Özellikle Abaka Han'ın ölümünden sonra eşi Mariya'nın Konstantinopol'e dönüşü evlilik akdinin gerçekleştiği andan itibaren sonsuza kadar devam etmesinin söz konusu olmadığını göstermektedir. Ancak bu türlü ilişkilerin başa gelen yeni imparatorlar tarafından tekrar edilmediği anlamına gelmemektedir. Nitekim Gazan Han döneminde benzer bir

tüccarına muamele etmesi gibi sebepler gösterilmektedir. Ayrıca Berke Han, Azerbaycan'daki Altın Orda haklarının iadesi için bir elçilik heyeti görevlendirmiş, ancak bu heyet üyeleri Hülagu tarafından önce esir alınmış, sonra da öldürülmüştür. Berke Han da bunun üzerine Azerbaycan'da görevli olan Altın Orda memuru ve taraftarlarından ülkelerine dönmelerini, bunu yapamazlar ise Memlûklere sığınmalarını istemiştir (Akkuş, 2016, s. 5-7). 
Oktay BERBER

evlilik akdi söz konusudur. VIII. Michael'den sonra Doğu Roma'yı yönetmeye başlayan II. Andronikos'un yine gayri meşru kızı İrene 1305 yılında Tebriz'e gönderilmiştir. Bu evlilik akdine de 1302 yılındaki Bizans elçilik heyetinin görüşmeleri sırasında karar verilmiştir. Pachymeres, II. Andronikos'un bu evlilik ile ilhanlı askerlerinin yardımını alarak Anadolu'da Selçuklu'ya karşı güvenlik oluşturma hedefinde olduğunu kaydetmektedir (Weller, 2016, s. 189 vd).

İlhanlılar, Doğu Roma hanedanlığı ile kurduğu siyasi evliliklerin bir benzerini Memlûklerle tesis etmişlerdir. Bu evlilikler han sülalesine mensup olan kadınlarla yapılan devletlerarası evlilikler ve Memlûk Devleti'ne iltica eden Moğol komutanlarının kızları ile yapılan evlilikler olmak üzere iki çeşittir. Yukarıda sözü edilen ve Berke Han ile Hülagu arasındaki ilişkilerin bozulmasına sebep olan olaylardan sonra Kermun, Nogay gibi komutanların aralarında bulunduğu bin üç yüz atlı olarak ifade edilen büyük bir grup Memlûklere sığınmış, 1262 yılı sonralında Kahire'ye ulaşan bu gruba iyi davranılması konusunda Baybars tarafından talimat verilmiştir. Yine aynı yıl içerisinde Berke Han'ın Saraghan Ağa adındaki komutanı da emrindeki iki yüz atıyla Memlûklere sığınmıştır. Sığınan bu komutan ve kişilere çeşitli emirlikler ve ıktalar verilmiştir. Memlûklere sığınan ilk grup içerisindeki Kermun'un kızı ile o dönemde emir rütbesine sahip olan Kalavun 1264 yılında evlenmiştir. Yine Kermun'un üçüncü kızı da Sultan Baybars ile evlenmiştir. Ayrıca Baybars'ın ve daha sonra Memlûk tahtına geçenlerin Moğollarla evlilik yaptığı bilinmektedir (Yiğit, 2016, s. 104-105, 108-109, 110).

\section{Sonuç}

Dönem kaynaklarındaki çeşitli örneklerden hareketle Moğolların 13. yüzyıldaki uluslararası ilişkileri, devlet yapısı ve işleyişi gibi hususlarda bir takım tespitler yapmak mümkündür. Yapılan inceleme neticesinde ilk olarak Moğolların kendi topraklarına giren diğer devletlerin temsilcilerine önem verdikleri, imparatorluk içerisinde oluşturulan posta teşkilatı (yam sistemi) ile elçilerin seyahatlerinin belirli bir sistem dâhilinde gerçekleştirildiği görülmektedir. Yabancı ülkelerden gelen elçilerin ihtiyaçlarının karşılanması, onlara saygı gösterilmesi, diğer ülkelere gönderilen Moğol İmparatorluğu temsilcilerine de aynı şekilde davranılmasının talep edilmesi Moğol idaresinin elçilere ve diplomasiye verdikleri değeri ortaya koymaktadır.

Moğolların diplomasi anlayışını yansıtan en önemli unsurlardan biri de gönderilen mektuplarda kullanılan ifadelerdir. Bu ifadelerde bir yandan Moğol idarecileri kendilerine gönderilen temsilcinin getirdiği mesaja cevap verirken diğer yandan devletlerinin büyüklüğünü ifade etmektedirler. Özellikle Moğolların askerî seferlerinden etkilenen bölgelerin tarih anlatımında yer alan Moğolların aşırı baskı ve yıkıcı seferlerinin sebepleri de mektuplarda dile getirilmektedir. Buna göre Moğol idaresi kendileri ile barış içerisinde olmayan ve gönderdikleri elçilere kötü davranan ülkelere askerî sefer düzenlemekten çekinmediklerini ve bunun için yeterince güçlü olduklarını ifade etmektedir. Kullanılan ifadelerden yola çıkarak Moğolların uluslararası ilişkilerde diplomasiye önem verdiğini, diplomasinin geçersiz kaldığı durumlarda savaş kararı aldıklarını söyleyebiliriz.

Uluslararası ilişkilerin kurulması, sürdürülmesi ve düşmanlara karşı ittifak arayışı içerisinde evliliklerin rolü de önemliydi. Buna dair aktarılan örneklerde bu uygulamadan Moğol idarecilerle birlik- 
te Moğollarla ittifak kuran devletlerin de siyasi, askerî ve iktisadi fayda elde ettiği görülmüştür. Yapılan görüşmeler sebebiyle tarafların birbirlerine hediye göndermeleri de tesis edilmeye çalışılan iyi ilişkiler için bir vesile sayıldığını ifade etmek gerekir.

Moğol İmparatorluğu'nda Çingiz Han döneminden itibaren elçilere duyulan saygı ve yaklaşım biçimi, onların bu büyük imparatorluk içerisinde güvenle seyahat etmelerinin sağlanması devletin idari mekanizmasının önemine işaret etmektedir. Ayrıca uluslararası ilişkilerde diplomasiye verilen öncelik ve değer doğrultusunda bozkırlı bir devlet olarak nitelenen Moğol İmparatorluğu'ndaki düzen, yönetim anlayışı ve organizasyon kabiliyetinin yüksek olduğu söylenebilir. Bu doğrultuda Moğolların Çingiz Han ile birlikte teşkil ettikleri yapı 13. ve 14. yüzyıllarda dünya tarihini siyasi, iktisadi, içtimai yönden etkileyen bir imparatorluk oluşturmalarında önemli olmuştur.

\section{Kaynaklar}

Akkuş, M. (2016). “Altın Orda-illhanlı Ilişkilerinde Dinin Rolü”, Turkish Studies, Vol. 11/11, s.1-12.

Aknerli G. (1954). Okçu Milletin Tarihi, (Çev.: Hırant D. Andreasyan), İstanbul Üniv. Edebiyat Fakültesi Yayınları, İstanbul.

Cengiz Imparatorluğu Hakkında ilk Tarih Kayıtları: Meng Ta pei lu ve Hei Ta shi lu, (2012). (Çev.: Ankhbayar Danuu, Haz.:. Mustafa Uyar), Ötüken Yayınları, İstanbul.

Cüveynî, Alaaddin Ata Melik (1999). Tarih-i Cihan Güşa, (Çev.: Mürsel Öztürk), Kültür Bakanlığı Yayınları, Ankara.

Dawson, C. (1955). The Mongol Mission Narratives and Letters of the Franciscan Missionaries in Mongolia and China in the Thirteenth and Fourteenth Centuries, Sheed and Ward, New York.

Dayı, Ö. (2015). “Câmiü't-Tevârîh'te Kubilay Han'ın Çin'deki İdarî Teşkilatı ve Bayındırlık Faaliyetleri", Atatürk Üniv. Edebiyat Fakültesi Sosyal Bilimler Dergisi, S. 55, s.239-255.

D’ohsson, A. C. M. (2014). Moğol Tarihi, (Haz.: Ekrem Kalan), IQ Kültür Sanat Yayınları, İstanbul.

Eberhard, W. (1987). Çin Tarihi, TTK Yayınları, Ankara.

Ergüven, N. S. (2016). "Uluslararası Hukukun Tarihsel Boyutuyla Diplomasinin Kuramsal Gelişim Süreci”, Ankara Üniv. Sosyal Bilimler Dergisi, C 7/1, s.111-141.

Ebû Abdullah Muhammed ibn Battûta Tancî. (2000). Ibn Battûta Seyahatnâmesi, (Çev.: A. Sait Aykut), CII, YKY, İstanbul.

Göksu, E. (2010). "Ok ve Yayın Türk Devlet Geleneği ve Hakimiyet Anlayışındaki Yeri”, Turkish Studies, Vol 5/3, s.986-1011.

Guangqi, S. (1993). "Zheng He's Expeditions to the Western Ocean and His Navigation Technology", The Journal of Navigation, Vol 45/3, s.329-343. 
Oktay BERBER

Han Hanedanlığı Tarihi (Hsiung-nu (Hun) Monografisi, (2004). (Haz.: Ayşe Onat vd.), TTK Yayınları, Ankara.

İskit, T. (2007). Diplomasi Tarihi, Teorisi, Kurumları ve Uygulaması, İstanbul Bilgi Üniv. Yayınları, İstanbul.

Johann de Plano Carpini (2000). Moğol Tarihi ve Seyahatnâme, (Çev.: Ergin Ayan), Derya Kitabevi. Trabzon.

Kalan, E. (2015). “Moğollar Devrinde İpek Yolu”, ipek Yolu Atlası, (Ed.: Ahmet Taşağı, Haz.: Fatma Yücel Ayık), Pelikan Basım, İstanbul, s.93-108.

Kalan, E. (2016). “Orta Çağ’da İpek Yolu'nda Diplomat ve Ajan Olarak Tüccarlar”, Yüksselen Ipek Yolu, Eed. Fahri Atasoy), C. II, Türk Yurdu Yayınları, Ankara, s.185-190.

Kamalov, i. (2005). “Altın Orda - Bizans Münasebetleri (1261-1453)”, Karadeniz Araştırmaları, C. 4 (4), s.3-20.

Koç, D. (2018). "Cengiz Han Sonrasında Moğollar”, Türk-Moğol Tarihi Bozkırın Avazı, (Ed.: Kürşat Yıldıım), Yeditepe Yayınevi, İstanbul, s.151-168.

Lessing, F. D. (2017). Moğolca-Türkçe Sözlük, (Çev.: Günay Karaağaç), TDK Yayınları, Ankara.

Ligeti, L. (2011). Bilinmeyen Iç Asya, (Çev.: Sadrettin Karatay), TDK Yayınları, Ankara.

Marshall, R. (1996). Doğudan Yükselen Güç Moğollar, (Çev. Füsun Doruker), Sabah Yayınları, İstanbul.

Minhâc-i Sirâc El-Cüzcânî. (2015). Tabakât-ı Nâsırî: Gazneliler, Selçuklular, Atabeglikler ve Hârezmşâhlar, (Çev.: Erkan Göksu), TTK Yayınları, Ankara.

Moğolların Gizli Tarihçesi, (2011). (Çev.: Mehmet Levent Kaya, Haz.: Ekrem Kalan), Kabalcı Yayınevi, İstanbul.

Mostaert, A. ve Cleaves, F. W. (1952). "Trois Documents Mongols Des Archives Secretes Vaticanes", Harvard Journal of Asiatic Studies, Vol 15 (3/4), s.419-506.

Ötemiş Hacı. (2009). Çengiz-Nâme, (Haz.: illyas Kamalov), TTK Yayınları, Ankara.

Özcan, A. T. (2010). “Macar Papaz Julian’ın 1237 Tarihli Moğol Raporu”, Ankara Üniv. DTCF Tarih Araştırmaları Dergisi, C. 29, s.89-99.

Özcan, A. T. (2013). "Moğol Tarihine Ilişkin Latince Kaynaklarda Uygurlar”, Selçuk Üniv. Türkiyat Araştırmaları Dergisi, S. 34, s.147-163.

Reşîuüddin Fazlullah. (2013). Câmiu't-Tevârih, (Çev. İsmail Aka vd.), TTK Yayınları, Ankara. 
Rossabi, M. (2008). Kubilay Han'ın Seyyahı Rabdan Savma ve Doğu'dan Batı'ya ilk Yolculuk, (Çev.: Ekin Uşşaklı), Türkiye İş Bankası Yayınları, İstanbul.

Roux, J. P. (2001). Moğol Imparatorluğu Tarihi, (Çev.: Aykut Kazancıgil-Ayşe Bereket), Kabalcı Yayınevi. İstanbul.

Sağlam, A. (2018). “Memlûk-illhanlı Diplomatik ilişkileri”, Belleten, C. LXXXII/293, s.83-157.

Sen, T. (2006). "The Yuan Khanate and India: Cross-Cultural Diplomasy in the Thirteenth and Fourteenth Centuries", Asia Major, Vol 19 (1/2), s.299-326.

Spuler, B. (1987). İran Moğolları Siyaset, Idare ve Kültür Ilhanlılar Devri, 1220-1350, (Çev.: Cemal Köprülü), TTK Yayınları, Ankara.

Taşağıl, A. (2013). Kök Tengri'nin Çocukları (Avrasya Bozkırlarında İslam Öncesi Türk Tarihi), Bilge Kültür Sanat Yayınları, İstanbul.

Turan, O. (1945). “Eski Türklerde Okun Hukukî Bir Sembol Olarak Kullanılması”, Belleten, C. IX/35, s.305-318.

Türker, Ö. ve Ükten, S. S. (2014). "Haçlılar, Moğollar ve Ortadoğu'da Haçlı-Moğol Münasebetleri”, Ankara Üniversitesi DTCF Dergisi, C. 54/1, s.319-344.

Türker, Ö. ve Karaduman R. (2018). "XIII. Yüzyılda Moğol-Avrupa Diplomatik Illişkilerinde Yaşanan Dönüşümler ve Rabdan Savma'nın Elçilik Misyonu", Selçuklu Tarihçiliğinin Zamansız Kaybı Feda Şamil Arık'a Armağan Türk Tarihine Dair Yazılar-III, (Ed.: Alpaslan Demir vd.), Gece Kitaplığı, Ankara, s.723-743.

Uluslararası ilişkiler Tarihi (Diplomasi Tarihi), (2009). (Haz.: Vladimir Potyemkin vd., Çev.: Attila Tokatlı) C. 1, Evrensel Basım Yayın, İstanbul.

Ver, M. G. (2011). "The Role of Information and Disinformation in the Establishment of the Mongolian Empire-A Re-examination of the $13^{\text {th }}$ century Mongolian History from the Viewpoint of Information History", Internatioal Conference on Integrated Information, (Ed.: Georgios A. Giannakopoulos-Damianos P. Sakas), Greece.

Ver, M. (2018.26.06). "Who were the elčis in the Mongol period", Diplomacy in the Age of Mongol Globalization (May 30-31, 2016), Erişim tarihi: 2018.01.07, http://mongol.huji.ac.il/sites/default/files/Ver Diplo 2016.pdf

Wei, Y. (2014). “Admiral Zheng He's Voyages to the West Oceans”, Maritime Asia, Vol. 19 (2), s.2630.

Weller, A.L. (2016). "Marrying the Mongol Khans: Byzantine Imperial Women and the Diplomacy of Religious Conversion in the $13^{\text {th }}$ and $14^{\text {th }}$ Centuries", Scandinavian Journal of Byzantine and Modern Greek Studies, No. 2, s.177-200. 
Oktay BERBER

Wilhelm Von Rubruk. (2001). Moğolların Büyük Hanına Seyahat 1253-1255, (Çev.: Ergin Ayan), Ayışı̆̆ı Kitapları, İstanbul.

Yiğit, F. A. (2016). "iktidar ve İzdivaç: Memlûk-Altın Orda-illhanlı Üçgeninde Siyasi Evlilikler”, Karadeniz Araştırmaları, S 46, s.103-120.

Yihao, Q. (2018.26.06). "To Share the Benefits and Legitimacy: Gifts Exchange in Diplomatic Practices in Mongol and Post-Mongol Eurasia", Diplomacy in the Age of Mongol Globalization (May 30-31, 2016), Erişim 2018.01.07, http://mongol.huji.ac.il/sites/default/files/Qiu Diplo 2016.pdf

Zhao, G. Q. (2008). Marriage as Political Strategy and Cultural Expression: Mongolian Royal Marriages from World Empire to Yuan Dynasty, Peter Lang Publishing, New York. 
Ek-1: Argun Han’ın Fransa Kralı IV. Philippe’e gönderdiği mektup (sağda) ve mektubun içerisindeki bir ayrıntı.
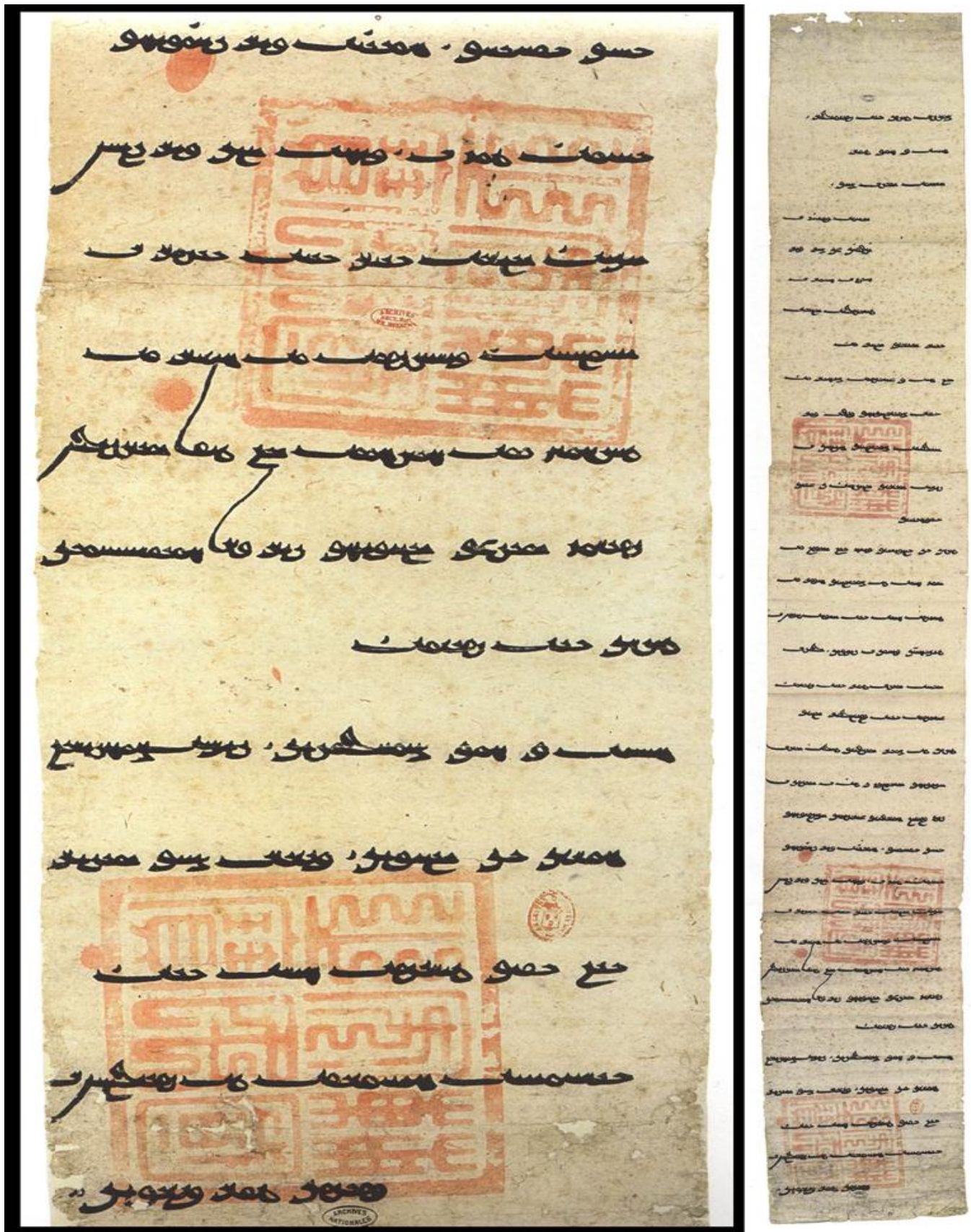


\section{Ek-2: Abaka Han'ın elçilere verdiği emir}

[1] [Aba - -]a üge manu.

$[\mathcal{2}]$

Samayar-a. ja $\gamma$ ura

[3]

bükün balayad-

[4]

un daru $\gamma$ as-ta

[5]

noyad-ta

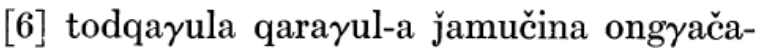

[7] čina. Bab-ača iregsed Baračirqun

[8] terigüten marqasiyas-a dabari $\gamma$ da $\gamma$ sad

[9] irgen ong $\gamma$ ačačin todqa $\gamma$ ul. ula $\gamma$-a

[10] umda sigüsü ana ülü megüdegülün

[11] ögüdkün. Yayud kedtür anu

[12] küčü buu kürgetügei. kembei.

[13] Bičig manu taulai jil öbül-ün

[14] terigün sara-in arban

[15] jir $\gamma$ u $\gamma$ an-a Aras-a büküi-

[16]

dür bičibei.

Abaka olarak emrimdir.

Samayar'da, yol üzerinde bulunan şehirlerin valilerine, kumandanlarına, posta istasyonları müfettişlerine, muhafız birliklerine, menzil istasyonları arası ulaşımı sağlayan kişilere, kayıkçılara.

Şöyle buyurdum: “Başlarında Baračirqun'un bulunduğu Papa tarafından gönderilmiş piskopos heyetine [yol üzerinde] rastlayacak ahali, kayıkçılar ve posta istasyonları müfettişleri, kendilerine her türlü menziller arası ulaşım hayvanı, içecek ve tayın verilecektir. Kendilerinin sahip oldukları eşyaları için [ellerinden almak için] sakın güç kullanmayasınız."

Mektubumuzu, Aras'ta iken tavşan senesinin kışının ilk ayının on altısında yazdık. 